\title{
The Imperial Republic and Pax-Americana: State Formation, Inequality, and the New American Way of War
}

\author{
Scott Timcke
}

\author{
School of Communication, Simon Fraser University, Burnaby, Canada, snt2@sfu.ca
}

\begin{abstract}
This article plots the complex historical interplay between state formation and militarized technology. What emerges is a portrayal of distributional consequences of particular means of rule and particular modes of warfare. I apply this framework to the New American Way of War, demonstrating that it structurally contributes to the widening economic inequality currently being experienced in the United States. In state formation literature, inequality is partly caused by how key technologies are militarized and deployed by the state for internal and/or external state building. Thus, inequality is the result of how the employment of particular kinds of military technologies affects the emergence and distribution of economic resources under different political regimes. By inference, the degree of inequality is a by-product of a state's means of rule. Hence, prior to the redistribution of wealth and economic chances by various state institutions, particular kinds of states are historically endowed with a predisposition to create and solidify social stratification. I offer a critical engagement with the new American Way of War through the lens of the means of rule. In my case study, I argue that due to technological choices, the American state no longer needs to be accountable to citizens or its subject population as a whole. In short, the American state can afford to disengage itself from wider negotiation and bargaining with its subjects. From the state's perspective, there is nothing these subjects offer to accent the current military capacity attuned to a particular military strategy. Simply, there is very little these subjects have that the state requires. Subsequently, if the current American Way of War continues, it is likely that arbitrary rule, militarization, and wide inequality will be the order of the day irrespective of who the particular governors happen to be.
\end{abstract}

Keywords: Inequality, The New American Way of War, State Formation, Empires, Means of Rule, Deep State,

Acknowledgement: Thanks are due to Catherine Hart, Graham Mackenzie, Jay MacKinnon, Milan Singh, and Jeff Whyte.

\section{Introduction}

By the late twentieth century Ralph Miliband declared, "More than ever before men now live in the shadow of the state" $(1969,1$.) But, contrary to Miliband, one prevailing belief during the 1990s was that the State was soon to be a redundant unit of analysis in political governance and international affairs. This was because multi-national corporations had transcended the regulatory capacity of any one particular state, while persons sensing state decline were reinvesting in cities to open political space to achieve their desired quality and way of life.

But even excluding the post-9-11 rise of the national security state it was an error to presume, like the hyper-globalists, that the state had ceased to be a viable political actor, or like the hyper-localists that the retreat to cities was an adequate political tactic. The state did not disappear in the 1990s; in fact, it was made even more present through acts of war, genocide, and economic reconstructing. Moreover, despite the conservative rhetoric of 'rolling back the state,' there has been instead an enormous centralization of power. Whereas modern democracies sought parliamentary or congressional systems, late modern democracies are executive democracies; faith is placed in the executive to provide goods, services, and to guarantee civility society. This trend holds irrespective of whether the issue concerns civil liberties, service delivery, or social provisions. All of this underscores the fact that presently the state commands the allocation of resources. Centralization has also allowed executive branches to justify the accrual of instruments of rule that can be used against dissidents and 
rivals. Indeed, historically states have been relentless in using force to accrue resources.

Observations linking political institutions and military technology have a long history in political philosophy. Aristotle wrote that "where the nature of the country can admit a great number of horse, there a powerful oligarchy may be easily established." He continues, "where the troops are chiefly heavy-armed, there an oligarchy, inferior in power to the other may be established [and] the light-armed and the sailors always contribute to support a democracy" (Aristotle 1778, 330). Thus, with its navy Athens was a proto-democratic maritime republic, while Thessaly with its cavalry suppressed democratic impulses. However, geographic elements also matter. Greece's rocky outcrops made chariots and cavalry ineffective while the spread of iron weapons broke the hegemony of bronze aristocrats.

While I shall add to these observations in the coming sections, my central proposition is how key military technologies prop up the state significantly induces the distribution of wealth in a society. In this respect, I submit that the prevailing widening inequality has deep historical-material roots and relates to a state's means of rule and force projection. Applying these principles to an analysis of the New American Way of War $=$ detailed below $=$ I argue that if this mode of warfare continues, it will exacerbate the already worrisome economic inequality in the US and solidify social stratification. As I demonstrate, this is because this mode of warfare has no functional need to be accountable to those who provide the necessary labour power required to reproduce the state. This has domestic as well as global ramifications for governance.

Methodologically I have adopted a historical macro-sociological approach to guide the analysis (cf. Tilly 1975 1990, McNeill 1982, Van Creveld 1999). Indebted to classical sociology, this approach traces the plurality of historical trajectories open to state development. By factoring in politics, internal social cleavages, and ideological choices the approach attempts to account for the development of diverse state forms. Special attention is given to how rulers acquire their means of rule and the resources required for effective warfare. Likewise, this approach is attentive to how those forms compete with diverse kinds of polities such as citystates, empires, and so on. So while historical and materialist in orientation, this analysis seeks to avoid the intellectual cul-de-sacs of crude materialism and reductionism.

In the interest of brevity I shall not offer an extensive defence of this method, nor parry with its intellectual rivals who indictments turn upon claims of inevitable decontextualisation or the violence of abstraction, suffice to say that administrative institutional and public choice approaches presume that all states are the inevitable by-products of failure to resolve collective actions problems (see Olson 1993, 2000; Levi 1988; Bates 2001). By contrast, the historical macro-sociological approach seeks to account for contingent outcomes of security and rule, extraction and extortion ${ }^{1}$. The configuration of different ratios between these items security and rule, extraction and extortion - is a kind of collective action as rulers co-opt and make alliances with different classes and subjects, or even seek to create and shape certain kinds of subjects.

The first half of the paper plots the complex interplay between state formation and the cost of - and degrees of access to - militarized technology. What emerges is a portrayal of distributional consequences of particular means of rule as this rule uses the opportunities presented by militarized technology. Several general observations are made. ${ }^{2}$ The second half

\footnotetext{
${ }^{1}$ While Tilly cautions against universalizing the European state-formation modal for other spaces and times "our ability to infer the probable events and sequences in contemporary states from an informed reading of European history is close to nil," $(1975,82)$ - he nevertheless thinks it is useful for regional and historical comparative and contrastive work. He writes that "the European historical experience, for all its special features, is long enough, well-enough documented, and a large enough influence on the rest of the world that any systematic conclusions which did hold up well in light of that experience would almost automatically become plausible working hypotheses to be tried out elsewhere" $(1975,13-14$.) Readers interested in state formation in other parts of the world, or the role of contextual elements such as family, or complex political authority can refer to Widner (1995) or Centeno (1997) as starting points.

${ }^{2}$ Certainly internal security dynamics are relevant, and internal/external actions rarely act in isolation of one another so one should not reify this divide, but due to brevity, I focus on external state formation, and set aside internal state formation dynamics for treatment at another time. Thus for instance when I discuss the military uses of drones, I set aside the politics surrounding the domestic deployment of drones.
} 
details the various aspects of the New American Way of War, showing that it fits a particular way of rule that need not necessarily rely upon the consent of citizens. I conclude that because of technological choices, the American state no longer needs to account to a wider pool of labour power. Therefore, the American state can afford to disengage itself from wider negotiation and bargaining with its subjects as a whole. From the state's perspective, there is nothing that subjects offer that can accent the current military capacity attuned to a particular military strategy. Simply, there is nothing subjects have that the state requires. Thus, in this analysis, there is little chance for the civilization of politics to continue. Lastly I discuss the imperial elements of this development, and what it might mean for domestic politics. ${ }^{3}$

\section{State Formation and Militarised Technology}

Consistent with a long traditional in political theory, I consider the state be an institution that collectivizes violence. As Skocpol writes, "any state first and fundamentally extracts resources from society and deploys these to create and support coercive and administrative organizations" (Skocpol 1979, 29). This requires that the state undertakes the "organization of armed forces, taxation, policing, the control of food supply, and the formation of technical personnel" (Tilly 1975, 6). But beyond these observations, the literature on state-building tends to split. On the one hand post-colonial and Marxist anthropologists and historians ${ }^{4}$ seek to demonstrate how subaltern groups resist, appropriate or help construct the state, highlighting how European state structures and national identities were constituted in part through imperial interests. Involved in this project is an extended analysis of the state acquires its reality in the daily experience, oppression, and division of working classes, and how they are put to work on imperial projects. Alternatively, orthodox comparative political sociologists are generally more concerned with how state rule is accomplished; as Skocpol puts it, "how states formulate and pursue their own goals" $(1985,9)$. Tied together they offer a complimentary analysis of state formation, identity, and global capitalism. As my interest in this paper rests with how military technology relates to rule, I tend to draw upon the second set of literature, but do try to keep an eye on the concerns over who happens to the subject of state violence.

Of late social scientists tend towards a nebulous definition of the modern state. Emblematic thereof is Schmitter, who defines the state as "an amorphous complex of agencies with illdefined boundaries performing a variety of not very distinctive functions" (Schmitter 1985, p33 as cited by Hay 1999, 153.) This is generally at odds with conventional Marxist takes which seeks to establish that the form and function of the capitalist state serve the requirements of the capitalist mode of production, and aids the reproduction of capitalist relations. But beyond the general claim that the state is a nodal point in capital relations, there is some disagreement about its precise mechanics. Colin Hay groups these mechanics under the labels "the state as the repressive arm of the bourgeoisie", "the state as an instrument of the ruling class,' and 'the state as a factor of cohesion within the social formation" (Hay 1999).

\footnotetext{
${ }^{3}$ In doing so, I set aside questions regarding the implicit or explicit place of empire in the history of political philosophy and the imperial dimensions of canonical political theorists' thought. The same holds for the supposed imperial tendencies in Liberalism, Marxism, and other universalizing political and moral responses that developed in light of, in response to, and sometimes in justification of imperial actions. I will also set aside questions regarding distinctions between imperialism and colonialism, as if setters working for the ends of an expansive power seeking domination over the affairs of a particular place to the ends of exploitative economic relations are not a method of imperial rule.

${ }^{4}$ Anthropologists have been known for their recalcitrant attitude towards the study of the state. For instance, Radcliffe-Brown (1963) in his preface to Fortes and Evan-Pritchard's African Political Systems, regarded the state as an ideological fiction. The state is "represented as being an entity over and above the human individuals who make a society, having as one of its attributes something called 'sovereignty,' and sometimes spoken of as having a will [...] or as issuing commands. The State in this sense does not exist in the phenomenal world; it is a fiction of the philosophers. What does exist is an organization, i.e. a collection of individual human beings connected by a complex system of relations" (1963, xxiii).

He sums up his position by saying that "There is no such thing as the power of the state" (1963, xxiii). Similarly, there have been scholars of governmentality (Burchell et el 1991) who suggest that state theory is a reification that eclipses a more detailed analysis of the microphysics of power.
} 
While any one of these takes may describe any particular capital-state relationship, applying more in some cases and less in others, each in their own ways gets bogged down when dealing with questions of bureaucratic agency (see Jessop 1990 for full details.) One way to avoid this gridlock is to follow Bob Jessop in understanding the state as "a specific institutional ensemble with multiple boundaries, no institutional fixity and no pre-given formal or substantive unity" (Jessop 1990, 267.) Jessop's model views the state as strategically selective, with structures and operations that while "more open to some types of political strategy than others," (Jessop 1990, 260) are not beholden to them. For Jessop there is no guarantee that the state will act as the bourgeoisie's repressive agents, further the interests of the ruling class, nor constitute a particular kind of society. Hay sums up this contingent approach as "there can be no general or fully determinate theory of the capitalist state, only theoretically informed accounts of capitalist states in their institutional, historical and strategic specificity" $(1999,171$.

I am persuaded by Jessop's argument about state actions in a capitalist society being contingent, indeterminate, and without guarantee, at least with regard to the intentions of capital itself. However, my historically informed intuition is that if one expands the scope of analysis to include states actions prior to capitalism one would find that the state has a consistent logic unto itself despite the presentation of seemingly contingent actions. This logic is that the state seeks to preserve and reproduce itself by being strategically selective and situationally responsive. I call this intention the deep state, the security kernel to which the 'amorphous complex of agencies' attaches to, these themselves having 'no institutional fixity' because they are situationally responsive strategic selections. In this respect, I think the question of bureaucratic agency and relative autonomy can be addressed by distinguishing between the securocrats of the deep state, who have a narrow agenda to maintain their power, and bureaucrats staffing the amorphous complex of agencies, whose actions are roughly permissible provided they do not conflict with the securocrats' goals ${ }^{5}$. This distinction offers one possible way of reconciling 'complexity' and 'coherence' positions staked out in the various on-going debates between state-as-society and state-in-society proponents. This bears out if one examines the history of state formation.

Prior to early pastoralism, behaviourally modern humans lived as hunter-gathers comprising of several extended families bound together by emotional ties. Overall these communities enjoyed relative equality of material and wealth distribution, similar interpersonal consumption and welfare levels while exhibiting limited social stratification. Notwithstanding natural precarity, these groups were somewhat peaceful, participatory, and cooperative. Additionally, they lacked a stable organization that maintained a monopoly of violence (see Lee and Leacock 1982 for an overview.)

Settled agriculture gradually took form from about 8'500 BCE, and preceded the formation of early states (cf. Thurston and Fischer 2007). Setting aside the bio-geographic reasons that prime some regions to develop agriculture, and the intermural debate for the reasons for this agricultural revolution, agriculture increases land productivity, but not uniformly. Thus a resource gradient is created. If combined with preferential and exclusive access to cultivated land, differential yields generate the first kinds of inequalities. However, as stone materials were readily available there is no advantage to be gained from political violence interceding to acquire particular land or yields. This is not to say that pre-states were absent conflicts or violence, but rather that these issues were essential to a centralised political institution. Thus while social structures were not egalitarian, they were not politically coercive either.

By approximately 4000 BCE the development of copper weapons and armour coincides with larger city-states in Mesopotamia (Barker 2006). The conventional explanation is that a warlord, using his technological advantage and forces, exerts control over a territory and population to loot and extract resources. In response, populations could either offer tribute in lieu of looting, or they could band together to establish a common defence against looters.

\footnotetext{
${ }^{5}$ Discussion of the state as an actor is so taken for granted that it is worth remembering that states do not and cannot act. So mentions of state actions or the deep state are but shorthand for the various people who staff and administer the organization.
} 
Both options open the door for proto-states. Thus one sees early settlements with fortified walls and shrines, such as Jericho, comprised of several thousand people under a centralized authority, some labour specialization, some marked inequalities, and political violence (see Finer 1997 for extended data). The similar patterns are found in Egyptian, Minoan, Mycenaean, Harrapan, Shang, and Mesoamerican civilizations.

Later, the introduction of bronze weaponry gave rise to military specialization; partly because the hardness of the alloy provided a military advantage, and partly because tin was scarce. Competition over these kinds of resources concentrated military might within certain classes, and exacerbated social positions such as rulers, agents, subjects, and looters which came to struggle over yields. For example, in ancient Greece possession of and access to these weapons align with class divides between aristocrats and peasants. This is not to claim that internal social differentiation is over-determined by militarized technology, but rather that political institutions depend upon military structures to enforce and preserve their rule.

McNeill (1982) has argued persuasively that the introduction of chariots around $1800 \mathrm{BCE}$ transformed warfare by providing relative battlefield advantages in manoeuvrability, effective range, and lethality. The average chariot could cause six casualties a minute at a distance of near 150 meters. Thus ten chariots could cause over a thousand causalities in ten minutes. But chariots were expensive, and increased the cost of war. This led the state being controlled by a wealthy warrior class. A disadvantage was that chariots lost their strategic value in mountainous or forested terrain. Pointedly, strategic and tactical advantages of particular militarised technology can have constraints of one kind or another. As an illustration of geographic influences, consider the relationship between heavy cavalry and European political development. Rogowski and MacRae (2008) attribute early medieval feudalism to the introduction of the stirrup. This allowed the cavalry to become militarily more effective, in turn consolidating their political aspirations, and is evident when examining the feudal regimes associated with Charlemagne and William the Conqueror. As negative cases consider how the semi nomadic Balkan highlanders avoided ruling elites, or late medieval Japan where mountainous regions were subdued only after the introduction of modern military equipment. Even stirruped horsemen were unable to operate as intended in these terrains. Similarly, Nordic forests were more conducive to infantry dependent militaries. Thus these societies did not share the orthodox feudalism experienced on the European plains.

Complementing the aforementioned relationship, Charles Tilly notes that around $1400 \mathrm{CE}$, European political elites used loans from merchants to hire mercenaries and expand their territory. But by the 1800s mercenary armies were no longer cost effective, their loyalty could not be guaranteed, nor could they field the same number of troops as a state with a professional army. Similarly, the strategic contribution of the cannon rearranged the state's internal distribution of power, removing it from feudal lords - leading to their demise - and concentrating it in the sovereign. ${ }^{6}$ This particular distribution of power devastatingly combined authoritarianism, economic stagnation, and inequality into a social form. The only thing to break this distribution of power was the industrial production of relatively cheap guns and the creation of conscripted armies. Absolutist regimes, well aware of what would happen to their power, tried to stave off nationally conscripted armies for as long as possible. As Boix (2011) explains,

After the defeat of Napoleon, the Austrian Prime Minister Metternich insisted on an explicit pact to abolish conscription at the Congress of Vienna. However, once the battle of Valmy (1793) and all the Napoleonic campaigns had demonstrated the superiority of universal conscription, most states ended up adopting some kind of standing army over time: Prussia immediately after the defeat at the hands of Napoleon, Russia after the Crimean war and Austria after its defeat at the hands of Germany.

\footnotetext{
${ }^{6}$ City-states could only resist the power of cannon once they built wide earth based walls that could deflect and absorb the impact of cannon.
} 
Reading with Tilly's points in mind, Boix's observation alludes to how technological developments and changes in the scale of warfare establish certain patterns of military affairs and organization as they become a prevailing mode of warfare.

A concurrent development was that the cost of warfare increased, and thus more financial resources were required. To collect and administer this capital extraction, rulers had to develop administrative capacities to manage logistical support for the centralized means of coercion and finance: Taxes had to levied; debts collected; investments managed and security forces paid (see Finer 1974, 98; Tilly 1990, 189-90; Tilly 1975, 73-74; Giddens 1985, 111 116). The finance to support these administrations came from taxing the wealthy, and exploiting the labour power of subject-populations. In return, some of these classes were granted limited political rights of representation, and the state had to invest in some services to keep its legitimacy; the state had to acquiesce to particular classes' political contention to retain their rule.

By approximately 1900 warfare became relatively more expensive. States therefore needed additional revenue, soldiers, and labour power to conduct warfare. One option was to draw upon and extract resources in the form of taxation and labour from their subjectpopulations. As I will explain in subsequent paragraphs, this development provided an opportunity for the bourgeoisie, and later the working class, to contend for political representation. In many cases these contentions were successful. Thus the advent of modern industrial war is linked with the extension of political rights (cf Levi 1997, Scheve and Stasavage 2010). But wider political representation meant that populations were more reluctant to engage in protracted wars, and this constrained the state's external violence.

From the study of state formation, Tilly classifies states according to revenue/extraction and coercion/violence spectrum. He identifies three main means of rule, coercion intensive, capital intensive, and capitalized coercion (Tilly 1990, 30). Coercion intensive sees the ruler use coercion to extract rents as resources are not under their direct control. Capital intensive rule occurs when rulers have direct control of resources and can exchange them to fund warpreparation. Capitalized coercion arises when wealth is relatively evenly distributed throughout the society. In response rulers tax subject populations or conscript their labour power. Tilly suggests that coercion intensive and capital intensive states tend not to need to rely upon the consent of the governed. They simply need to control agents who will do their bidding. By contrast, because wealth is diffused through the population a capitalized coercion state will have to strike a bargain with their subjects. In return a state enters a contract committing to obligations with subjects, and setting standards for compliance and, thus acquiring legitimacy.

The expansion of administrative apparatuses has a consequence for state politics. It prompts civilians to make claims upon these administrations and rulers. Tilly calls this the "the central paradox of European state formation" describing the process as "the pursuit of war and military capacity [...] as a sort of by-product, led to a civilianisation of government and domestic politics" (Tilly 1990, 206). I understand him to mean that as rulers come to rely upon using civilian life as resources for war, so civilian populations become better positioned to bargain with rulers. Simultaneously the administrative class could also petition rulers to provide more resources to them, they made claims themselves under the bargain of withdrawal of services. This increased the extent to which civilians decreased the asymmetrical power ratio between the state, themselves, and other functionary groups. This is known as the civilianization of politics through the changing civilian constituency of politics.

The civilianization of politics represents an opportunity for civilians to constrain rulers. As civilians enter into arrangements wherein they bargain compliance, this, at once, gives them leverage in the political bargaining process. This is because as rulers demand funding for their military, so civilians can withhold these funds. As Tilly writes, "Under these circumstances, the most a ruler can hope for is grudging consent."7 Grudging consent "depends

\footnotetext{
7 This is similar to Adam Przeworski's (1985) observation that working class movements rarely adopt a revolutionary agenda. This is because they lack the power to decisively transcend capitalism. These movements therefore seek a class compromise, where their power to damage capitalism is acknowledged and concessions are proportionately granted, such as minimum wages, and workplace rights. Similarly with grudging consent, citizens
} 
critically on how rulers acquire the means to rule" (Tilly 2009,1). While resources vary over time "the principle remains the same: Effective rule depends on the continuous production of crucial resources. If the resources dry up, rulers lose the means of enforcing whatever decisions they make and state capacity collapses" (Tilly 2009, 1). Non-democratic regimes differ from democratic ones insofar that they gather resources through coercion as opposed to extraction. Subsequently, there is some space in democratic societies to set limits on extractive activates. Citizen-Subjects have "substantial power to accept or reject their demands" by exercising their "voice" (Tilly 2009, 1). Tilly thinks there is "political value [in] grudging consent" because "It means that citizens and their representatives remain properly wary about the harm that rulers may do" (Tilly, 2009,1.)

For Tilly, democracy is the "outcomes of continuous negotiations between rulers and ruled over how resources for governance are acquired and subsequently how they are used" (Tilly 2009 , 3). He argues that a sustainable democracy is unlikely without a state extracting resources from a set population, for if the state does not need to extract resources, then the voice of citizens has no bearing upon how governance is conducted. Tilly writes that, "In mature democracies, most negotiation between leaders and citizens centre's on government's performance - how resources are used" $(2009,3)$. He proposes that it is the rulers desire to seek control that leads them to bargain with the population. Resistance to unjustified extraction is the path towards democracy, resistance to extraction requires that rulers bargain with populations, thus promoting democratization ${ }^{8}$. By taking advantage of tensions between rulers and the ruled, there is scope to balance compliance and grudging consent such that citizens get service delivery, and the state maintains nominal control. Democratization turns on how citizens can collect together to resist the excessive extraction of the state, and "develop the breadth, equality, binding and protection of their voices" in a manner to express when the state is out of bounds (Tilly 2009, 7).

State formation is a process by which a state accumulates power, and grows in economic productivity through the use of a system of rule which has coercive, administrative, and fiscal dimensions. It does so in part by building political and institutional capacities through the consolidation and expansion of bureaucracy to extend command and control capacities. These capacities are used to eliminate, neutralize or disarm rivals. Here less efficient polities capitulate and succumb to those who are more efficient. In this framework, war-making leads to state consolidation, integration, and pruning of political polities, eventually converging on a basic type of polity, but whose variation hinges upon differential mixtures of coercion and capital. Randall Collins provides an excellent summary of this process, which is worth quoting at length:

The state originates as a military organization, and expands by military conquests (e.g. Prussia) or alliances (e.g. Dutch); military costs are the biggest item in the state budget; the 'military revolution' in size and expense of troops, weapons and logistics leads to creation of administrative apparatus (bureaucracy) to extract revenues. From here on several historical pathways can be followed: resistance by aristocrats and populace to revenue burdens and administrative encroachment can lead to state breakdown and revolution, or alternatively to authoritarian restoration, or to state disintegration; what happens to states which take the latter pathways is usually a fatal geopolitical weakness that ends the independent history of that state. In the long run, the states which survive are those which successfully expand their tax extraction and administrative organization; and this penetrates into society, breaking down patrimonial households, inscribing individuals as citizen-subjects of the state, and thereby creating mobilizing conditions for modern mass politics, and for state welfare administration (Collins 2004, 5).

lack the power to decisively overthrow their rulers, but do have enough power to damage the political system, hence some concession are granted.

${ }^{8}$ How rulers acquire rule provides the conditions under which democratization and accountability and the civilianization of politics may be possible. For a treatment of this subject see Tilly 2009 
While state formation literature could take a more sustained treatment of military-capital relationships, the general findings should not necessarily come as a surprise to those familiar with Marx, who conceived of the state as a relationship between the police and management orientated internally, and militarily and diplomatic efforts orientated externally, and these processes themselves mediated by alliances and political maneuvers with particular social classes.

The distribution of income is also shaped by the way rulers extract their resources and the kinds of alliances they form with different strata of producers. However, as weapons and military planning becomes more complex and expensive so the production of violence will lead to the professionalization of war-making. Specialization factors into the creation of a strong centralized state, as the state only has to negotiate with those who are able to contribute substantially to their coffers; the distribution of income becomes skewed as rulers ally with the richest fraction of the population; perhaps imposing a lower extraction rate for example. Thus a highly extractive fiscal system and social inequality will prevail. Distribution becomes more unequal the smaller the number of rulers relative to a population. The ruling elite controls capital-extraction in its territory through monopolizing the means of coercion while offering protection and security to its subject-populations. On occasion, there have been organizational and technological changes that have broadened the political base of government; democratizing them and reducing inequality and the distribution of income and power. In this respect, equality is the result of a particular uniform distribution of resources in relation to a specific technology of production.

I have argued that the political institution is partly a function of military technology, but I also want to make it clear that advances in military technology do not automatically lead themselves to the creation of centralized and hyper-hierarchical structures. Rather it is when and where rulers have a monopoly of force and can acquire their resources without necessarily bargaining with producers that rulers can extract at a rate of their discretion. States and their allies thus have interests in protecting this status quo and in blocking processes of economic and political liberalization.

While several elements influence the variable success of particular technological, social and political combinations, what is analytically important in the state formation literature is that the degree of inequality is partly caused by how key technologies are militarized and deployed by the state for internal and/or external state building. In other words, inequality is the result of how the employment of particular kinds of military technologies pursuant to a particular military strategy affects the emergence and distribution of economic resources under different political regimes.

\section{The New American Way of War}

To provide some background, the 'American way of war,' a phrase coined by Russell Weigley (1960), is a mode of modern industrial warfare employing strategic attrition. First deployed in the American Civil War, and constantly refined until World War Two this mode of warfare drafted and mobilised citizen-soldiers to leverage and deploy mass-industrial output as unprecedented firepower. However, the development and strategic deployment of nuclear weapons made total industrial strategic attrition unfeasible between nuclear-armed states. Subsequently, nuclear weapons initiated the shift from the industrial mode of warfare to the political nature of limited asymmetrical warfare. This is partly why wars since 1945 have been limited conflicts.

One key ramification of this shift is where once civilians were targeted because of their labour power - for example in fire and saturation bombing - in a political conflict a population's ideological attention and beliefs are terrain to be fought over and occupied. Where once the means of rule were limited to controlling resources such as weapons, food, and labour power, now rulers require a scientific-technical complex and communications media to attend to beliefs and perceptions. Domestically, this means that total industrial labour mobilization is unnecessary, rather it is their loyalty to continue supporting foreign deployments that is required. Consequently, this arrangement creates conditions where wars could be lost because 
of the lack of domestic public political support. In this respect, military efforts and affairs are internally and externally directed; they are internal with respect to ensuring that public opinion does not negatively affect the state's extraction of resources, and externally against designated combatants. Supporting this orientation is not only a technological innovation, but also a reorganization of the strategic approach to the way of waging war. Along with many others (Boot 2003, Echevarria 2004; Hudson, Owens and Flannes 2011) I call this this New American Way of War.

To show this link more concretely, I propose that one understand the New American way of war as an outcome of how the national security establishment has reconfigured its military force. Having assessed recent US military budgets and policy statements (Department of Defence 2012a, 2012b), I suggest it has five formal features. These are the use of a 1\% military complemented by the use of private security contractors, increasingly automated lethal robotics such as drones, reliance upon Special Forces, cyber-warfare and dragnet surveillance, and sinocentric naval containment. These methods attempt to minimize cost and risk of American casualties while increasing force projection and the maintenance of Pax Americana. However, it does so with minimal civilian oversight and by disregarding standing norms in international law. Additionally, this new mode of military planning and operation seeks to accomplish political goals in an age of diminishing budgets, a push for a more compact force, and a public and institutional distaste for occupation and nation building. I shall briefly cover these features, drawing attention to their military nature and political ramifications in line with the theoretical external state formation model advanced in the previous section.

\subsection{A $1 \%$ Military and Contractors}

Military theorists generally presume that industrial democracies are loath to become involved in protracted conflict. This is because citizens carry the costs in the form of taxation and life as they directly participate in warfare. This sentiment is attributed to George Marshall that "a democracy cannot fight a seven year war." So democracies use representative oversight, dissent, and protest to safeguard against needless military efforts. In general, this squares with Tilly's observations about the civilization of politics discussed above.

However, should the deep state desire protracted conflict, one method to alleviate protest would be to insulate the burden of war from the wider civilian population. Ending conscription ensures that citizens are relatively untouched by war. A professional military removes the immediate responsibility of war, i.e. combat, from citizens, and by relegating it to the state the conditions exist for more blatant imperial projects. The closing of American-Vietnam war provided just such an opportunity. In many respects a professional military suited the political elite, military officials, and the public. For the political elite a professional army would ease widespread resentment. For the military it could move the institutional culture away from drug use, ill-discipline, and insubordination amongst the troops. And the public would no longer be unwillingly drafted. In the main, the middle class was insulated from the threat of conscription. In the post $9 / 11$ world, this has meant that less than $1 \%$ of Americans have served in the military, and that these troops have been disproportionately drawn from economically vulnerable and improvised communities. It is my contention that this ' $1 \%$ army,' has been equipped and mobilised to protect and advance the interests of the economic $1 \%$, the power elite whose occupy key positions in the deep state.

In recent remarks General Stanley McChrystal has captured the downside of this approach. He said that the American public is insulated from the New American Way of War, and this only prolongs conflict allowing contractors to profit and damage to be exacerbated. His solution to address these issues would be to reinstate the draft. As I will show over the next few pages McChrystal's remarks indicates a remarkable lack of awareness that the New American Way of War - given he was key architect thereof - no longer has need for a draft. 
Due to domestic politics, in August 2011, the Obama administration began defence spending cuts totalling near half a trillion dollars over 10 years. ${ }^{9}$ In part, the latent rationale is to produce a military that is more efficient by, for instance, eliminating obsolete procurement, closing unnecessary bases, and streamlining commands. Included in this plan is a reduction of military personnel by almost 100 '000 by 2017 , four fifths of which would be Army personnel.

This budgetary squeeze coincides with the US's reorientation, from the Middle East to the Asia-Pacific region. While I will detail this development below, put simply, it means that the US State will try to move beyond both counterinsurgency and counterterrorism operations and towards more strategic concerns. The ramification for the Army is its attempt to remain central to this new strategic re-orientation while active involvement in major combat operations is curtailed. But given the strategic reorientation, the current Army Chief of Staff General Odierno has conceded that the army will be sidelined and relegated to conducting strategically secondary missions such as assisting with peacekeeping in Africa, regime stabilization in Latin America as well as continuing counterinsurgency and counterterrorism operations and occupations (Odierno 2012). Odierno predicts that these operating environments will feature "regular military and irregular paramilitary or civilian adversaries, with the potential for terrorism, criminality, and other complications" (Odierno 2012, 1)

To meet this diverse mission mandate the Army is seeking to put logistic hubs in key locations, while units seeking regional alignment by including language skills, dedicated kinds of equipment, and cultural training to attend to different missions and different physical, political, and cultural environments. The goal is have an army that is used as a deterrent as part of a broader security plan. Odierno says that "This means maintaining a force of sufficient size and capacity so that potential adversaries understand clearly our ability to compel capitulation if necessary". He continues, "we will increasingly emphasize activities aimed at deepening our relationships with partners and demonstrating our country's commitment to global security. Ideally, a focus on prevention and shaping will keep future conflicts at bay" (2012).

To supplement this regional realignment, the United States has been using private military contractors - mercenaries - as a way to publically claim that they have few troops committed to an area of operations. In August 2011, for example, there were more than a quarter of a million mercenaries in Iraq and Afghanistan (Commission on Wartime Contracting 2011).

By using volunteers and contractors to bear the brunt of military labour, the conditions exist to go to war for extended periods without genuine accountability to the public. Indeed the deep state can bypass attempts to garner public legitimacy for conflicts and military interventions. In other words, citizens' views are not central to ascertaining the costs of military adventurism. Moreover, volunteer military tend to encourage the ideological predisposed sign up. This further distances the military from the values within the society.

Another item of concern, due to the increased use of Special Forces, is that the building and maintenance of major foreign bases is in decline. Rather minimalist outposts that can be built or discarded as required are becoming the norm. Even Afghanistan, where the American Army is expected to be deployed until 2024, follows this pattern. Cost is a certainly a prime factor in this decision. This is not to argue for the virtue of American citadels occupying foreign soil, but rather to underscore the shift in military planning.

An additional feature of the Army recalibration of military planning and operations is how it seeks to fully integrate technological capabilities into frontline units, thereby extending advanced technology and the information revolution to the individual solider. Although Odierno admits that goal is still years away from operational deployment, there is certainly a research agenda which involves the construction of an "operator suit". Initial specifications for this computerized suit include night vision and other tools to enhance situational awareness, enhanced strength, ballistic protection, and a life support infrastructure. As these kinds of advanced technology and the information revolution affect the individual solider, so it provides them with force multiplication. This means that the state requires fewer soldiers to deploy

\footnotetext{
${ }^{9}$ Although discretionary spending is set to increase by approximately $\$ 109$ Billion, see http://www.whitehouse.gov/sites/default/files/omb/budget/fy2013/assets/defense.pdf
} 
similar levels of force, effectively concentrating the skills and capability of warfare with selected agents.

Internally, the state seeks to lionize the military in an attempt to forestall critical appraisals of its activities. This is evident in the rhetorical pairing and purposeful conflation of unreserved support of troops with unreserved support for the operations in which they are involved. These moves seek to quash criticism while ordinary people unreservedly repeat war apologetics, thereby capitulating to ideological dogma. Indeed, the military and its personnel are publically positioned as beyond reproach. The military being a prime delivery instrument of humanitarian aid and the subject of gaming and cinematic narrative assist in internal public relations exercises. This has been so successful that even allegations of atrocities are met with undue suspicion and unqualified blanket defence before an investigation has taken place. All in all, this culture of solider worship blinds the public to the realities of war and occupation, obscuring rather than addressing the issue of imperial conflict.

\subsection{Special Forces}

Since the end of the Gulf War, Special Forces have been become a key foreign policy instrument. In 2010, near 4000 Special Forces troops were stationed in approximately 60 to 75 countries (excluding Iraq and Afghanistan), with efforts to expand both of those numbers. Bearing the hallmarks of a flatter organizational structure and close collaborations with intelligence agencies, these units are designed to respond in unilateral direct covert action, training, and joint operations with security partners. These last two options are, however, just meant to provide a cover of legitimacy (Scahill 2010). As these forces are rarely accountable to other branches of government, the result is that in effect, the presidency and the national security state are consolidating a private military force, near $66^{\prime} 000$ and expanding, to compliment the CIA (Schmitt, Mazzetti and Shanker 2012). This number has doubled since 2001 and includes military personal and Defence Department employees. Similarly, in the same time period spending has increased from $\$ 4.2$ Billion to $\$ 10.5$ Billion. With this funding, 12 '000 Special Forces troops have been deployed every day since 2003, with four-fifths located in the Middle East conducting up to 14 raids a night (Robinson 2012). Therefore it is an uncontroversial observation that the US state is relying upon Special Forces to an unprecedented degree, and this is particularly fruitful in times of fiscal restraint.

These forces have more presidential access under Obama than previous administrations, who is allowing these forces to act in an aggressive, secretive, and pre-emptive manner. Emblematic of this mode of operation is the group formally known as Task Force 714 . This group is sanctioned to work without coordinating with embassies and controls an armory which includes cutting edge weaponry and robotics.

As per Jeremy Scahill's reporting, White House counterterrorism director John O. Brennan has articulated this agenda as the US "will not merely respond after the fact," but will "take the fight to al-Qaeda and its extremist affiliates whether they plot and train in Afghanistan, Pakistan, Yemen, Somalia and beyond" (Scahill 2010). Bureaucratically, this traces to a Bush era order called the AI Qaeda Network Execute Order which permits Special Forces to be deployed beyond the battlefield for lethal and covert operations and sanctions crossborder operations.

One should not discount the policy sway of Special Forces in advocating a move away from large missions to more flexible operations (see Ackerman 2009). In this line, Special Forces Command has been advocating for more autonomy to position troops and equipment as per their judgement about global affairs (Schmitt, Mazzetti and Shanker 2012). The idea behind this re-orientation is to be able to respond rapidly to broad and emerging threats, while avoiding large-scale foreign interventions and occupations. Accordingly, Special Forces are seeking new kinds of missions. However, this petition is not without dissent in some areas of the Pentagon-particularly area commanders and the State Department - which believe covert force to undermine diplomatic relations. Furthermore, this particular request for more autonomy would bypass Pentagon, the Joint Chiefs of Staff, and the Defence Secre- 
tary, let alone democratic oversight (Schmitt, Mazzetti and Shanker 2012). Internal critics thus claim Special Forces are empire building.

Notwithstanding these criticisms, the political turf wars seem to be regularly won by Special Forces. For example, when he was the Defence Secretary, Panette, upon the request of the Special Forces, broadened their operational purview by granting it a global combatant command. In addition to global responsibility this effectively gave Special Forces the ability to reallocate troops to regional commanders bypassing Pentagon oversight ${ }^{10}$. This modification would grant Special Forces a greater degree of autonomy to determine threats as per their intelligence operations, although, operations would still be directed by the president. This allows Special Forces to conduct missions that could otherwise be stalled by the Pentagon, effectively making Special Forces akin to a Praetorian guard. Furthermore, due to a perceived degree of autonomy, this organization insulates the executive power with plausible deniability should things go awry.

The dominant place and clout of Special Force is so entrenched that the US Army, in an effort to remain relevant, is seeking to train its general purpose units to provide logistical support, menial labour, and regional specialization (See Odierno 2012) to Special Forces units. In effect, Special Forces are calling the shots. As Robinson (2012) remarks,

These changes will allow special operators to deploy in an integrated fashion with other elements of the U.S. government, including conventional military forces, in well-thought-out campaigns that will last not days but years and achieve durable positive effects.

Robinson adds that other departments should "assist in the execution of any new plans".

Even as the military is downsized and refocuses on the Asia-Pacific region there is no indication that the Special Forces budget will be reduced, or that Special Forces unit deployments will be curtailed. Rather it appears that their troop levels will stay consistent, just reallocated to other regions (see Schmitt, Mazzetti, and Shanker 2012). It is envisioned that their missions will be to stay on call for direct action against terrorist targets and hostage rescue operations. Further, using the pretence of training and liaison missions, they will be used to collect information in unorthodox ways. In short, the Obama administration has made Special Forces a central tool in enforcing global rule.

Special Forces have also supported the Drug Enforcement Agency in Latin America (Scahill 2010) as well as conducting independent operations. For example, in Honduras Special Forces use Forward Operating Base Mocoron to train counter-narcotics Honduran troops in counter insurgency tactics (Turse 2012). Even more worrying in some respects is that using military forces in an international policing capacity, involves the militarization of police forces and other government agencies. For instance, there is little to differentiate a DEA Foreign deployed Assistance \& Support Team agent from a Special Forces operator. The same has held for tactical units in domestic policing for some time (Kraska and Kappeler 1997, Shank and Beavers 2013).

\subsection{Automated Lethal Robotics and UAVs/Drones}

All branches of the military are researching or seeking to develop robotic instruments of war. The US Navy is attempting to build armed submarines and helicopters such as the Fire Scout. As of writing, the Marines are testing Gladiators, small tracked vehicles armed with machine guns which are intended to operate in front of advancing troops, while the Army uses Packbots to assist in bomb detection and detonation. Using funds provided by the Defense Advanced Research Projects Agency, several companies are iteratively making hominoid-esque robots like Boston-Dynamics' Atlas. Bio-mimicry extends to pack animals such as the BigDog and drones that look like birds (McDuffee 2013). Suffice to say that even

\footnotetext{
${ }^{10}$ Regional commands could appeal the to the Pentagon for adjudication, but given that Special Forces are shielded by Presidential authority, the Pentagon's scope for discretion is it is not yet clear.
} 
if the military budget were to shrink, these kinds of robotic systems are deemed to be crucial piece of future military capacity, force, and planning. To examine this trend, I use the case of drones.

First used for tactical reconnaissance, drones have become a near indispensable battlefield technology with offensive capabilities. From 2002, when a couple of strikes targeted Salim Sinan al-Harethi and Nek Mohammad - with an estimated High Value Target to Total Deaths ratio (HVT:TD) of 1:5 - the offensive use of drones escalated from 2005 onwards. Eventually, between 2009 and 2010, there were 161 strikes, killing 1029 persons with a HVT:TD ratio of 1:147, suggesting indiscriminate targeting (Hudson, Owens, and Flannes 2011). The most recent phase of the drone program is characterized by an increase in attack frequency, sanctioning targets of opportunity, and likely larger payloads exacerbating civilian deaths. From 2011, the Obama administration announced plans to begin an aggressive new drone-warfare campaign in Yemen directed against al-Qaeda in the Arabian Peninsula, Somalia (Mazzetti 2011), as well as providing drone support to foreign nations such as Uganda and Burundi in addition to anti-piracy operations in the Indian Ocean (Turse 2011). Due to the multiple areas of operation, state secrecy, and absent reports, it is difficult to estimate how many casualties drones have caused in recent years.

Drone warfare has been marked by so called signature strikes. Daniel Klaidman describes signature strikes as "targeting of groups of men who bear certain signatures, or defining characteristics associated with terrorist activity, but whose identities aren't known" (Klaidman 2012) and Greg Miller (2012) describes them as "surgical, often lethal, and narrowly tailored to fit clearly defined U.S. interests". This is particularly distressing when the US military is testing software which will program drones to automatically hunt, identify and engage targets (Finn 2011). Combined with revelations about NSA mass surveillance there is little to inspire confidence that future signature strikes will not automatically scrape big data gathered through data mining.

The Obama administration overruled the use of signature strikes, preferring instead Terrorist Attack Disruption Strikes (TADS). However, as Miller reports, TADS are aimed at "wiping out a layer of lower-ranking operatives through strikes that can be justified because of threats they pose to the mix of U.S. Embassy workers, military trainers, intelligence operatives and contractors scattered across Yemen." But by that definition, it seems that TADS and signature strikes are practically one and the same (Miller 2012). And if anything, one can infer from Miller's report that the US has inserted trainers, operatives and contractors into Yemen in an effort to erode the threat presented by AQAP (but itself likely inducing blowback.)

The American public is told that extrajudicial casualties from drones are primarily militants but these claims remain unsubstantiated and under investigated even as strikes have become routine (Sokol 2010). The Brookings Institute estimates that 10 civilians are killed for every militant. It seems the official line is similar to that provided in the Vietnam War; 'anybody dead was considered a VC.' This method is used in areas as from Northern Mali on the Islamic Maghreb and the Philippines's Abu Sayyaf and Jemaah Islamiyah (Oumar 2012, Ahmed 2012). The lack of judicial oversight, superseding legal constraints, extra-judicial killings, massive collateral damage, the summary execution of American citizens, secret 'kill lists,' and the uncertainty caused by the lack of transparency and accountability leaves little information for a proper public debate. The administration claims they follow strict internal reviews to prevent abuses, but there is no way to verify these claims. What has happened is the installation of an undemocratic and illiberal self-regulating centralised authority yielding lethal force. Therefore, the intellectually responsible position is to be suspect and critical of this politically centralised bombing.

The State claims that greater transparency, while desirable, must be weighed against revealing the sources and methods of the intelligence community, and the 'requirement of nonacknowledgement.' The former reason seeks to preserve a tactical edge over enemies, but this does not explain why representatives or the judiciary cannot provide oversight. The later reason indicates cooperation with other countries whereupon operational involvement is unacknowledged, and official credit of tactical successes are taken by the host country. Here 
the Yemen, Philippines, and Mali governments insist they carry out strikes, even while lacking the capability to do so (Booth and Black 2010). The upside is that their sovereignty appears to remain intact. However, by not acknowledging external involvement, this is withholding crucial information from their citizens. And there is a clear link between secretive power and abusive practices. This is why modern democratic states have checks and balances.

As it has been conducted, drone warfare seems strategically misguided and even exacerbates strategic confusion. This form of warfare is hardly decisive and it incurs significant political and diplomatic costs. Target populations live in constant terror of being attacked. And non-combatants' death and feelings of asymmetrical vulnerability, even if they are not ideologically sympathetic to local combatants, creates incentives for the target population to retaliate against convenient targets. Altogether, drone warfare, rather than bringing stability has simply compounded violence and instability. But it appears as if this cost is acceptable because it gives an under-informed public the impression that potential conflicts and attacks are being averted.

Strategically drone warfare sees US covert, overt, and diplomatic agencies working at cross purposes, producing strategic and tactical confusion (Chin 2007). Similarly, given the states in which they are used, drones destabilizes already frail an ambiguous political systems by inflaming social volatility and isolating populations from political elites and governance structures which are seen as powerless to stop this terror (Crilly 2011). In Pakistan, for instance, the CIA wants the drone campaign to continue unabated, whereas the State Department argues that the drones risk destabilizing a nuclear power (Entous, Gorman, and Rosenberg 2011).

In 2011, it was known that the United States operates approximately sixty drone bases planet wide (Turse 2011, Whitlock and Miller 2011), and the Obama administration plans for more bases in Japan, South Korea, and Niger. Similarly, in the first half of 2013, the US Navy on separate occasions successfully launched and landed an automated X-47B drone from an aircraft carrier. Currently, software running the X-47B is being tested for inflight refuelling. These developments can increase surveillance and reconnaissance capabilities, but to see them as isolated or minor events is to miss the point that they are a key part of a constantly expanding project of global surveillance.

Despite being crash-prone, requiring good operating conditions (Turse 2012), and are easy to target hence their deployment to safer operating area, proponents promote drone warfare as more precise and discriminating, hence more militarily effective and even ethically obligatory (cf. Strawer 2012). They cite additional benefits such as minimal 'footprints,' payload variability for weapons and surveillance, as well as their long range and extended flight times all at a relatively low production cost, compared to manned aircraft. ${ }^{11}$ Proponents further suggest that the moral questioning of this mode of warfare is factually incorrect, confused, or misguided. For instance, Peter Beaumont does not distinguish between which weapon has caused injury and death (Beaumont 2012.) He argues that the central question is whether a weapon system is used in line with prevailing international conventions and norms:

In conflict, within the existing framework of international humanitarian law, whether an attack is justifiable and legal is defined both by the nature of the target and proper consideration of whether there will be civilian casualties and whether they are avoidable (Beaumont 2012).

Therefore, Beaumont concludes, "the notion of drone warfare [is] not more horrible than a Tomahawk cruise missile fired from a distant ship or a bomb dropped indiscriminately on a village by a high-flying F-22 or MiG". By inference, what matters is the existence of targeted killing program, not the instrument. Moreover, an excessive focus on the instruments blurs the key issue, which is the willingness to use deadly force to further imperial aspirations. The right question to ask of drone warfare, Beaumont thinks, is whether

${ }^{11}$ Basic models cost $\$ 4.5$ million 
as a military tool, drone warfare is actually effective; whether its use is justified when set against the political fallout that the drone campaign has produced and whether drones have actually reduced the threat posed by militants.

This subjective utilitarian view of military tools is not an engagement with morality and ethics, but simply a political calculation regarding technology use where drones are just another tool to apply lethal force. In this respect, Joseph Singh, a research at the Center for a New American Security sees no qualitative difference between drones and piloted aircraft in terms of the application of lethal force. He writes, "any state otherwise deterred from using force abroad will not significantly increase its power projection on account of acquiring drones" (Singh 2012). Other commentators present the false choice between national insecurity or assassinations as if there were no better ways to achieve security, peace, and justice.

Opponents of drone warfare, such as Michael Ignatieff suggest that drone proliferation has changed the nature of warfare (2012.) In a passage worth citing at length, he writes

\begin{abstract}
In his essay 'Reflections on War and Death' French philosopher Jean-Jacques Rousseau "asks the reader what he would do if without leaving Paris he could kill, with great profit to himself, an old mandarin in Peking by a mere act of his will. Rousseau implies that he would not give much for the life of the dignitary." Imagine if great numbers could so exercise their will. What violence would be unleashed, how many prostrate bodies around the globe who never knew what hit them? (Igantieff 2012)
\end{abstract}

It is a telling passage which remarks on the ease of killing and not bearing the consequences for the act thereby lowering the threshold for public acquiescence to conflict. Reduced-risk operations lessen political aversion to commission attacks in official and unofficial conflict areas. This enables conditions where strikes become more frequent and militaries less prudent in their use of force relative to the industrial mode of war. This, in turn, contributes to and exacerbates existing conditions (such as political repression and famine in the case of Yemen, sectarian turf wars in the case of Pakistan, or a failed state in the case of Somalia) thereby producing more enemies. The deception is that "these new technologies promise harm without consequence," Ignatieff says, but "there is no such thing." Proponents of drone warfare miss the point that distance - physically and psychologically - is an ethical matter.

In the final analysis, it appears as if foreign drone strikes serve two functions. The first is to engender domestic political satisfaction amongst an otherwise blasé public. And the second is that the greater part of the Middle East is a laboratory for operational testing in advance of future conflicts. Not to put too fine a point on it, the military adventurism in the Middle East is, in part, a technological proving ground for the other aspects of the New American Way of War. The apparent ease of operational deployment means that missions can be run with minimal accountability; hence military force is more aggressive and less discriminating. This is important to consider given that military technological pathways are prone to becoming locked in by the market in one way or another. There is little to suggest that effects from the efforts to robotize the battlefield will be any different.

\title{
3.4. Cyberwar and Dragnet Surveillance
}

The US is trying to exploit digital infrastructure for total information awareness and military advantage. It would be unwise to underplay the danger and significance of this emerging capability to expand the range and kind of harm, and the implications for national and international security (for an extended treatment of this issue see Kello 2013). Touted as a revolution in military affairs and doctrine there is still too much that remains unknown about technological volatility and defence complications which could lead to strategic instability. Emblematically, there is tremendous confusion over Stuxnet, the first publicly disclosed cyberweapon. Due to a lack of information about the weapon itself, questions abound about who 
deployed it, and the extent of sabotage at the Natanz uranium-enrichment plant and the IR-1 centrifuge control system (Langer 2013).

So the unknown cyberwar has initiated an arms race to build capacities, gather resources, and train staff. The United Kingdom has established Academic Centres of Excellence in Cyber Security Research. Co-sponsored by the Department for Business, Innovation and Skills, the Centre for the Protection of National Infrastructure, GCHQ, the Office of Cyber Security and Information Assurance, and Research Councils UK, these centres are meant to assist the research into cyber-security as outlined in the UK Government's National Cyber Security Strategy. In short, trying to get everyone 'on page' as it were and training staff for the developing cyber warfare infrastructure. Eleven universities have so far joined the program including Cambridge, Oxford, as well as the formally left leaning University College London. But this is a race with no direction and without an understanding of pace.

Gartzke (2013) has an insightful comment into this development. He writes that conflict over the internet is much more likely to serve as an adjunct to, rather than a substitute for, existing modes of terrestrial force. Indeed, rather than threatening existing political hierarchies, cyberwar is much more likely to simply augment the advantages of status quo powers. (Gartzke 2013)

Digital society and the global explosion of digital information have made possible dragnet surveillance and efforts by security officials to access collect data at the unnecessary expense of civil and digital liberties. While one should not discount the role and lobbying done by the emerging cyber-industrial complex, or the politics involved, it is clear that the US State has weaponised the internet.

An internal NSA strategy policy document (2012) reveals that the agency views its mission as "dramatically increas[ing] mastery of the global network" and acquiring communication data the agency deems of strategic value from "anyone, anytime, anywhere." To do so the agency has tried to petition for legal and policy accommodations and adaptions, undertaken liberal interpretation of existing laws, or it has disregard them altogether to pursue their objective of mass surveillance. This is justified by appeals to the demands of the information age:

The interpretation and guidelines for applying our authorities, and in some cases the authorities themselves, have not kept pace with the complexity of the technology and target environments, or the operational expectations levied on the N.S.A.'s mission. (NSA 2012)

The NSA has even bragged about this being "the golden age of Sigint" (NSA 2012, 2.) Similar to the Pentagon's Human Terrain System - a militarized anthropology whose ostensible purpose consists of a computerized system of statistical demographic information on occupied populations with the aim of providing actionable military intelligence - so too do NSA projects seek to profile populations. One project, Mainway, in August 2011 was collecting data from near 2 billion phone records per day. From what little is publically known, this project used Section 702 of the 2008 FISA Amendments act to force American service providers to give data on Americans' calls to foreign nations (Risen and Poitras 2013a). The 2013 NSA budget request seeks to increase data collection capacities to record 20 billion events per day as well as a system which can integrate different data streams within the hour to create bulk data, then to share that data for more effective analysis (Risen and Poitras 2013a).

Another project, Treasure Map, collects network and geo-location data of between 30 and 50 million ISP addresses to map and track "any device, anywhere, all the time". The NSA (2012) has routinely sought to influence and spy on the commercial entities and the standardization bodies that set particular encryption specification. Framed as in the interests of cybersecurity, these particular standards make it easier for the NSA to exploit them. Other kinds of actions may be possible, but this is unknown as the NSA's Operations are secret, so too are legal proceedings concerning the scope of these activities. On the odd occasion when warrants are required, the agency goes to the Foreign Intelligence Surveillance Court, whose proceeding and rulings are classified. 
The goal of all this surveillance is for the US state to maintain its dominance in intelligence collection. In 2010, it emerged that the NSA has been piloting the analysis of massive communication data to model networks of associations and build profiles ostensibly for intelligence purposes. These profiles can be augmented by public records and third party record compliance from banks, social media sites, and GPS location information (Risen and Poitras 2013a). Data analysis is used to infer friends and associates and build behavioural and movement patterns should the need arise to track or attempt to predict individuals' actions. This behaviour has established norms for other states to follow, in effect making all traffic, private and public, on the internet fair game and legitimate targets. Moreover, these conditions are primed for institutional abuse.

Under current law, aspects of the NSA's data-mining practice is legally binding (cf Smith $v$. Maryland 1979 and Patriot Act 2001) and is understood by the NSA to apply "without regard to the nationality or location of the communicants" (as reported by Risen and Poitras 2013a). But prima facie the scope is in no ways acceptable in a basic fundamental justice framework. It presents the most serious attack on free speech and liberty in the modern period. As Levy crisply observes, "The chilling of free speech isn't just a consequence of surveillance. It's also a motive" (Levy 2013). The constant threat of direct monitoring with privacy being de facto non-existent, and the affective anxiety caused by it, is anathema to liberty. Authoritarians claim these measures are for public safety, but in actual fact, this surveillance is internally directed to preserve the regime, not to ward off external threats. Such social conditions fracture civic life as it is impossible to trust others. In addition, the prospect of blackmail looms, as does the prospect of evidence acquired without due process, or trumped up evidence, in an attempt to forestall protest. The point is not whether this or that administration will or will not act in this way, but rather that the infrastructure is in place with the implicit latent rationale that it ought to be used; the state establishes an infrastructure that it 'won't control,' rather than 'can't control.' In this way, public safety is threatened by the state, not by an external threat.

When these items are discussed in public, the State co-opts human rights language in justification of the national security state. But this is an inversion of what actually happens, when the national security state erodes civil liberties. This is near obvious when examining the proportionality of policy actions that what is taking place is systematic pervasive surveillance. In the contemporary state of affairs surveillance is arguably more pervasive than under most authoritarian and totalitarian regimes of the past. As Heidi Boghosian, notes "corporations and our government now conduct surveillance and militaristic counterintelligence operations not just on foreign countries but also on law-abiding U.S. citizens working to improve society," and whole "lives are subjected to monitoring, infiltration, and disruption once they are seen as a threat to corporate profits and government policies" $(2013,21)$. Indeed, the NSA has been collecting information in anticipation of discrediting dissidents, but this collection fails to meet the standard of probable cause.

The state, with the assistance of corporations such as AT\&T, Facebook, Google, and Verizon, has built an extensive intelligence gathering infrastructure using programs like PRISM, XKeyscore and other strategic information operations to build dossiers. When whistle blowers speak up or newspapers or journalists investigate these state actions the state uses intimidation tactics or character assassination. This has happened with Chelsea Manning, Julian Assange, Edward Snowden, and Glenn Greenwald. And in so doing, the intelligence apparatuses are demonstrating that they are wilfully ignoring the laws, presuming to be above them.

Despite the NSA's effort to reassure American citizens that its actions are not as nefarious as press reports indicate, and that all data queries relate to foreign intelligence efforts such as counterterrorism, counter-proliferation and cybersecurity, time and time again, claims about the NSA's lawfulness and conscientious protection civil liberties are demonstrated to be false. Similarly, its claims of thwarting attacks are drastically overstated. Foreign Intelligence Surveillance Court Judge John Bates in a recent ruling painstakingly catalogued "pervasive violations" of previous court orders, rampant "unauthorized electronic surveillance" of 
US citizens, and a "history of material misstatements" about how NSA programs worked (Bates as cited by Gosztola 2013). So the agency has a credibility gap.

Cross state partnerships are also common place, thus circumventing laws and political accountability. From 2008 the NSA and Britain's Government Communications Headquarters (GCHQ) gained access to OPEC to gain publically unreleased information on oil production (Spielgel Staff 2013). Similar efforts have been directed to energy companies, financial organizations, and foreign governments. As another example, the US and Japan will cooperate on cyber-security issues as the US pivots to the Asia-Pacific region.

The danger of this massive data gathering exercise takes on another dimension as domestic Government Agencies seek to adopt drone programs for domestic law enforcement. For instance the FBI, Homeland Security, and Coast Guard deploy these resources for border patrol and drug surveillance and interdiction. Even police in Miami are field testing drones for police operations. It would be an error to downplay these concerns as in previous instances the NSA has shared criminal evidence with law enforcement agencies, who in turn who then misattribute the source of their information, or in hindsight manufacture chains of evidence when arresting a suspect (Menn 2013). In additional to making a mockery of due process principles, with this level of inter-governmental cooperation there are good grounds to suspects that the NSA will have access to that drone information.

\subsection{Naval Containment and Pax-Americana}

Traditionally, US foreign policy has been Eurocentric, either for commerce or for confinement to decrease European influence in the Western Hemisphere (Stepak and Whitlack 2012). Thus European stability and economic growth was to be balanced with a degree of military caution as European powers were prime trading partners but also posed the greatest security threats.

But given geopolitical global power shifts, US Foreign Policy is becoming Sinocentric ${ }^{12}$. This sentiment can be seen in the various Presidential and Pentagon Strategic documents (see Department of Defense 2012a, 2012b, Daggett 2010, Obama 2007). In much the same way that the US viewed European economic growth and trade as beneficial while being circumspect about security concerns, the US has adopted the same stance to China in an attempt to cater simultaneously towards strategic balancing and economic development. To accomplish this goal the US will continue to trade with China while presenting a muscular posture by establishing and maintaining military superiority (see Department of Defense 2012a, 2012b, Daggett 2010, Obama 2007). This military presence takes the form of large naval exercise with allies, distributing troops from Japan and South Korea to the Philippines, Australia, and other parts of the region, and donating equipment (Burke 2013, Gonzanga 2013). Other actions include deploying (but not basing) littoral combat ships in Singapore ${ }^{13}$. These actions suggest that the US is seeking to reassure US regional partners with symbolical commitments while displaying a show of force to deter attack and nullify China's own military show of force. The weighted decision to move troops from South Korea and Japan mollifies the posture of direct confrontation, cedes strategic space to China so as to avoid conflict, and protects its forces from certain kinds of missiles.

Given that much trade travels via seas the orthodox understanding of global trade is that it is underwritten by naval power. States that have the ability and power to enforce the movement of goods in such a way that they are insulated from regional violence are the economic hegemons. In line with orthodoxy, the United States deploys its Navy to enforce PaxAmericana. This power is backed by the ability to direct sustained combat operations on, over, under, and adjacent to the sea using naval aircraft, marines, or missiles. China, while

\footnotetext{
${ }^{12}$ The Clinton administration was first to deemphasize a Eurocentric posture, and plans were in place to organize with a rising China in mind (Stepak and Whitlack 2012). This was a defence priority in the recent Bush administration until September the $11^{\text {th }}$. However, the Obama administration has returned to these issues.

${ }^{13}$ The Malacca Strait is an energy chokepoint for China. As a majority of the country's energy flows through this region it is ripe for blockade.
} 
not yet possessing the naval presence or the force to displace Pax-Americana nevertheless has, the US believes, sufficient force to disrupt US hegemony in the Western Pacific.

It is with this strategic caution in mind and the need to regulate the flow of goods that despite military spending cuts, the Navy will not cut or reduce any of its 11 aircraft carrier task forces (New York Times Editorial 2012). Rather, there is recapitalization of these military resources. Take for instance the new Ford class carrier. At $47^{\prime} 000$ tons and with an expected deployment in 2016, this class of aircraft carrier features a redesigned flight deck to launch and recover aircraft far more efficiently than the currently operating Nimitz generation. ${ }^{14}$ Additional improvements include new designed propulsion systems, reactors, and radar (Terdiman 2013). Carrier groups are re-locatable airports, bases, and factories and are used to coordinate force projection; a form of $21^{\text {st }}$ century gunboat diplomacy.

As another example, the USS Ponce, a former transport ship, has been refitted to become a floating forward operating base. Already deployed to the Persian Gulf, capabilities include helicopter pads and maintenance facilities with the addition of underwater diver support, and barracks to support several hundred Special Forces troops. The advantage of this platform is that it is not dependent on foreign nations to provide land for bases. The Navy is requesting a further $\$ 1.2$ Billion in its budget for two similar but purpose built vessels. At the time of writing these vessels are under construction with the first ship is due to become operational in 2015 (Shanker 2012).

The orthodox view holds that military pre-eminence yields significant economic benefits through reducing security tensions thereby assuring safety to investors. Presumably the stability that Pax-Americana brings is an international public good. That said, there are some who are sceptical about the extent to which this naval orthodoxy fulfils the promise of structured economic benefit (cf. Drezner 2013 as a notable example). The rough counterargument is that international security threats are less likely for stable states, but rather more likely for failing states and those resisting global integration. So, the sceptics conclude, there is no need for a sizable naval presence.

However, the sceptics overlook that the US Navy allows the US to dictate the terms of global economic and political integration. The purpose of the US Navy is not to expunge rivals per se, but to use the prospect of force to consolidate control over economic activity, and the standards and norms that govern that activity. This rebuttal is stronger if one considers the observations made by David Graeber in Debt (2011) about military force and contemporary international political economy. He argues that one core instrument of rule that a state using military power to control financial liquidity. He writes that

The essence of U.S. military predominance in the world is, ultimately, the fact that it can, at will, drop bombs, with only a few hours' notice, at absolutely any point on the surface of the planet. No other government has ever had anything remotely like this sort of capability. In fact, a case could well be made that it is this very power that holds the entire world military system, organized around the dollar, together (Graeber 2011, 365).

For states of considerable strength, like the US, they can use their money supply to act as an international reserve currency. This is particularly effective when there is 'gunboat' issuing of US treasury bonds as a form of tribute together with the aggressive deployment of financial instruments and institutions in rolling out and maintaining Pax-Americana ${ }^{15}$. Recent historical precedents for this way of rule include the manner in which US used NATO, the manner in which the USSR used the Warsaw Pact, and the imperial powers use of local strongmen or warlords as agents to prop up regimes in return for preferential market access and tribute.

Considered from this vantage, what appears as the loss of centralised US control of capital is rather a strategy of external capital extraction that involves demanding that other states

\footnotetext{
${ }^{14}$ This is the first new aircraft carrier class since the USS Nimitz in 1968, and America's first new carrier of any kind since the USS George H.W. Bush was completed in 2003.

${ }^{15} \mathrm{My}$ goal in this section is less the precise detailing of these mechanics and more the efforts to connect naval power with the extraction and state rentiership.
} 
pay tribute to the US. Within this means of extraction corporations have been granted privateer-like-license to pursue their profit making (and keep a healthy dose of profit themselves) in return for maintaining the system of rule. Privateer-corporations establish themselves in suitable host states and begin capital extraction operations. To assist in this endeavour, the host state's regulatory capacities are undercut through resource starvation, reduced budgets, and undermining state capacity. This is the creation of new markets for corporations to fill, and while it might initially look attractive because these corporations are selling under-priced public goods, it comes at the cost of sovereignty and local political discretion. It is a refinement of indirect rule through financial tools through the deployment of tasked extraction agents in service of a racketeering and rentiering operation. Put in other terms, transnational enterprises have been deliberately unshackled by American policy choices to create indirect rule using agents, as opposed to direct territorial occupation.

In return the US, through the Navy and other agencies, provides security to corporations to do business. This is accomplished either through rigging international treaties, capturing international organizations, or lobbing and bullying for favourable business relations in host countries. Basically, the state seeks to create global governing structures to maintain a rule set to which other countries must abide. And should corporations not comply with their side of the bargain they risk sanction and being excluded from benefits and contracts.

\section{Concluding Remarks}

My analysis has emphasised how a state's pursuit of strategic goals using militarised technologies shapes its political system and social structure. As outlined and discussed above, it appears that the New American Way of War is both internally and externally directed. Politically, it is a system which no longer seeks the basic pretence of governing with public accountability in mind. Militarily, it is a system with the capacity to deploy force against internal dissidents and rivals at will. Internationally, it is a system of indirect rule on a global scale.

This combination of direct internal coercive extraction, external indirect capital extraction, and extortion under the guise of security for tribute creates an unstable social system prone to inequalities. Domestically, the bargaining process between subjects and rulers which led to democratization will likely be eroded as increasingly portions of the subject-population cannot offer items rulers require for their strategic pursuits. Therefore these persons are deemed politically dispensable and basic services and welfare provisions are curtailed or withdrawn. Instead, the state will make strategic selections catering to those it deems valuable or whose support it requires to continue ruling. This development not bode well for the civilization of politics.

Part of the success of the US deep state has been its ability to mobilise privately organized industrial strength, and has directed the dividends to new technological developments cementing state-capital relations in the military industrial complex while periodically intervening into popular culture to create soft power. As Barry Posen remarks, the US has "command of the commons - command of the sea, space, and air" $(2003,7)$. Naturally this raises questions of imperialism.

My analysis of global indirect rule, extortion, and gunboat diplomacy is at odds with the analysis offered by Hardt and Negri (2000). Reminiscent of Kautsky's superimperialism, Hardt and Negri argue that the transnational of capital has subordinated states as instruments serving and imposing capitalist imperatives. Thus orthodox understandings of the $20^{\text {th }}$ century interstate system are no longer tenable given current circumstances. But beside from too hastily announcing the end of state sovereignty, Hardt and Negri neglect that systematic cooperation between capitalist states reflects the prevailing balance of power. Agreements are but a means to maximise returns upon extraction at any given time, and should new methods emerge, or should the balance of power shift, so strategic selections would change. This understanding of interstate co-operation as tentative, contingent, and without guarantee neatly aligns Jessop's understanding of the state.

As an alternative, by empire, I follow Calhoun et el's (2006) description that it "is a political unit that is large and expansionist (or with memories of an expansionist past), reproducing 
differentiation and inequality among people it incorporates [and annexes]". To this one should add, what territories are deemed unworthy of incorporation and thus left to fend for themselves, as well as semi-autonomous regions and client states. But empire is not just the accumulation of land by conquest, nor necessarily authoritarian and draconian rule. Rather it is a kind of polity. As Maier remarks,

Empire is a form of political organization in which the social elements that rule in the dominate state [...] create a network of allied elites in regions abroad who accept subordination in international affairs in return for the security of their position in their own administrative unit (Maier 2006, 7)

He adds that empires tend to be differentiated in numerous ways, but that the political organization seeks to stabilise these differences by "reconciling some rituals and forms of equality with the preservation of vast inequality. The empire is large enough that zones of violence and zones of pacification can usually be kept apart" (Maier 2006, 23) Further, empires are scalar:

They replicate their hierarchical structures and their divisions at all spatial levels, macro and micro - at the level of the community and the workplace as well as the continent. Hospitals, offices and factories, shopping malls and markets, stadiums, airports and bus terminals, housing (from gated communities to urban projects), and so on all recapitulate the social structure of the whole (Maier $2006,10)$

With these remarks in mind, it is odd to hear choruses maintain straight-faced that PaxAmericana provides a global public good (Ignatieff 2003, Ferguson 2004) or that it not an empire, primarily because the US initially seceded from an empire and has not conquered and incorporated land. However, it is as if the belief in manifest destiny is so strong that it discounts US actions in the Philippines, Cuba, Caribbean and Pacific islands, a history of military adventurism and installing puppet governments in Latin America, let alone being a settler society which dispossessed native's land and enclosed them into reservations and exceptional domains. Disregarding this history basically amount to affirming an ideologically presumed historical summons with apparent restraint of the use of force to bring peace and security to a turbulent world politics beset with illiberal hordes. Moreover, presuming that a degree of democratic control and liberal constitutionalism makes a state immune from imperial behaviour and authoritarian governance in foreign territories does not stand up to scrutiny. Since the Second World War US experience has seen the initiation and execution of warfare removed from the orbit of legislative control, and pulled towards the deep state. Once these items are laid out, the denial of empire becomes untenable.

To conclude, with apologies to Edward Gibbon, America is an empire disguised by the forms of a democratic republic. If the current American Way of War continues, it is likely that arbitrary rule, militarization, and wide inequality will be the order of the day irrespective of who the particular governors happen to be. How this politics is meant to promote the liberty, well-being, and human-flourishing of ordinary Americans, citizens in the states that mimic this mode of warfare, and persons living elsewhere, is unclear.

\section{References}

Ackerman, Spencer. 2009. Special Operations Chiefs Quietly Sway Afghanistan Policy. The Washington Independent, November 9

Ahmed, Akbar. 2012. Deadly Drone Strike on Muslims in the Southern Philippines, Brookings, March 5, http://www.brookings.edu/research/opinions/2012/03/05-drones-philippines-ahmed

Aristotle. 1778. A Treatise on Government. William Ellis' translation, Project Gutenberg, http://www.gutenberg.org/files/6762/6762-h/6762-h.htm 
Barker, Graeme. 2006. The Agricultural Revolution in Pre-History: Why Did Foragers Become Farmers? Oxford: Oxford University Press.

Beaumont, Peter. 2012. Are Drones Any More Immoral than Other Weapons of War? The Observer. August 19, http://www.guardian.co.uk/commentisfree/2012/aug/19/peter-beaumont-drone-warfaredebate

Boghosian, Heidi. 2013. Spying on Democracy. San Francisco: City Light Books

Boot, Max. 2003. The New American Way of War. Foreign Affairs, July/August 2003, http://www.cfr.org/iraq/new-american-way-war/p6160

Booth, Robert and lan Black. 2010. Wikileaks Cables: Yemen offered US 'open door' to attack alQaida on its soil, The Guardian, December 3. http://www.theguardian.com/world/2010/dec/03/wikileaks-yemen-us-attack-al-qaida

Burchell, Graham, Colin Gordon and Peter Miller, eds. 1991. The Foucault Effect. London: Harvester Wheatsheaf

Burke, Matthew. 2013. 20,000 US troops descend on Australia for training, Stars and Stripes, July 17

Centeno, Miguel Angel. 1997. Blood and Debt: War and Taxation in Nineteenth-Century Latin America. American Journal of Sociology 102 (6): 1565-1605

Chin, Warren. 2007. Examining the Application of British Counterinsurgency by the American Army in Iraq, Small Wars \& Insurgencies. 18 (1): 1-26

Collins, Randal. 2004. Gorski and the Military-Fiscal Theory of State Penetration. Comparative \& Historical Sociology 15 (4): 5-6

Commission for Wartime Contracting. 2011. Transforming Wartime Contracting, Final Report to Congress, August 2011

Crilly, Rob. 2011. Protest against American Drone Attacks in Northern Pakistan. The Telegraph, June 20.

Daggett, Stephan. 2010. Quadrennial Defence Review 2010. Overview and Implications for National Security Planning, Congressional Research Service.

Department of Defence. 2012a. Sustaining US Leadership: Priorities for 21st Century Defense, January 2012

Department of Defence. 2012b. Joint Operational Access Concept, January 2012

Drezner, Dan. 2013. Military Primacy Doesn't Pay (Nearly As Much As You Think). International Security, 38(1): 52-79

Echevarria, Antulio. 2004. Towards an American Way of War. Strategic Studies Institute, http://www.dtic.mil/futurejointwarfare/ideas_concepts/echeverria_american_way_of_war.pdf

Entous, Adam, Siobhan Gorman, and Matthew Rosenberg. 2011. Drone Attacks Split US Officials, The Wall Street Journal, June 10.

Ertman, Thomas. 1997. Birth of the Leviathan: Building states and regimes in medieval and early modern Europe. Cambridge: Cambridge University Press

Ferguson, Niall. 2004. Colossus: The price of America's empire. New York: Penguin Press

Finer, Samuel. 1997. The History of Government From the Earliest Times. New York: Oxford University Press

Finer, Samuel .1974. State-Building, State Boundaries, and Border Control. Social Science Information 13: 79-126

Finn, Peter. 2011. A Future for Drones: Automated Killing, Washington Post, September 19

Gartzke, Erik. 2013. The Myth of Cyberwar: Bring War in Cyberspace Back Down to Earth. International Security 38 (2): 41-73.

Giddens, Anthony. 1985. The Nation-State and Violence. Berkeley: University of California Press.

Gonzaga, Robert. 2013. Philippine war games tied to US pivot strategy in Asia. Stars and Stripes, June 28

Gosztola, Kevin. 2013. NSA Sent Home Talking Points for Employees. The Dissenter, December 2, http://dissenter.firedoglake.com/2013/12/02/nsa-sent-home-talking-points-for-employees-to-use-inconversations-with-family-friends-during-holidays/

Graeber, David. 2011. Debt: The First 5000 Years. Brooklyn: Melville House

Hardt, Michael and Antonio Negri. 2000. Empire. Cambridge: Harvard University Press

Hays, Colin. 1999. Marxism and the State. In Marxism and Social Science, ed. Andrew Gamble, David Marsh, and Tony Tant, 164-171. London: MacMillan.

Hudson, Linda, Colin Owens, and Matt Flannes. 2011. Drone Warfare: Blowback from the New American Way of War. Middle East Policy 18 (3): 122-132 
Ignatieff, Michael. 2012. Drones Give Democracies No Cause for War, Financial Times, June 12, http://www.ft.com/cms/s/0/10a03278-b3b3-11e1-a3db-00144feabdc0.html

Ignatieff, Michael. 2003. Empire lite: Nation-building in Bosnia, Kosovo and Afghanistan. Toronto: Penguin Canada.

Jessop, Bob. 1990. State Theory: Putting the Capitalist State in Its Place. Cambridge: Polity

Johnson, Chalmers. 2006. Nemesis: The Last Days of the American Republic. New York: Metropolitan Books.

Kello, Lucas. 2013. The Meaning of the Cyber Revolution: Perils to Theory and Statecraft. International Security 38 (2): 7-40

Klaidman, Daneil. 2012. Drones: How Obama Learned to Kill, Newsweek, May 28, http://mag.newsweek.com/2012/05/27/drones-the-silent-killers.html

Kraska, Peter and Victor Kappeler. 1997. Militarizing American Police. Social Problems 44 (1): 1-18

Langer, Ralph. 2013. Stuxnet's Secret Twin, Foreign Policy, November 19, www.foreignpolicy.com/articles/2013/11/19/stuxnets_secret_twin_iran_nukes_cyber_attack

Lee, Richard and Eleanor Burke Leacock, eds. 1982. Politics and History in Band Societies. Cambridge: Cambridge University Press.

Levi, Margaret. 1988. Of Rule and Revenue. Berkley, CA: The University of California Press.

Levi, Margaret. 1997. Consent, Dissent, and Patriotism. Cambridge: Cambridge University Press.

Levy, Josh. 2013. NSA's surveillance programs are the "most serious attacks on free speech we've ever seen." Boing Boing, August 22, http://boingboing.net/2013/08/22/opinion-nsas-surveillancep.html

Maier, Charles. 2006. Among Empires: American ascendency and its predecessors. Cambridge: Harvard University Press

Mazzetti, Mark. 2011. US Is Intensifying a Secret Campaign of Yemen Airstrikes. The New York Times, June 8

McDuffee, Allen. 2013. Army Scores a Super-Stealthy Drone That Looks Like a Bird, Wired, 27 November 2013, www.wired.com/dangerroom/2013/11/army-maveric-microdrone/

McNeill, William. 1982. The Pursuit of Power: Technology, Armed Force, and Society since AD 1000. Oxford: Oxford University Press.

Menn, Joseph. 2013. Secret U.S. court approved wider NSA, Reuters, 19 Nov 19 www.reuters.com/article/2013/11/19/us-usa-nsa-spying-idUSBRE9Al11Y20131119

Miliband, Ralph. 1969. The State in Capitalist Society. New York: Basic Books.

Miller, Greg. 2012. U.S. drone targets in Yemen raise questions. Washington Post, June 2.

New York Times Editorial. 2012. New Strategy Old Pentagon Budget. New York Times, January 29

NSA. 2013. SIGINT Strategy 2012-2016, February 23

Obama, Barack. 2007. Renewing American Leadership. Foreign Affairs 86 (4).

Odierno, Raymond. 2012. The U.S. Army in a Time of Transition. Foreign Affairs 91 (3).

Olson, Mancur. 1993. Dictatorship, Democracy, and Development. American Political Science Review, 87 (3): 567-576

Olson, Mancur. 2000. Power and Prosperity. New York: Basic Books

Oumar, Jemal. 2012. Mystery Airstrike kills Azawad Terrorists, Magharebia June 22, http://magharebia.com/en_GB/articles/awi/features/2012/06/22/feature-01

Posen, Barry. 2003. Command of the Commons: The Military Foundation of U.S. Hegemony, International Security 28 (1): 5-46

Przeworski, Adam. 1985. Capitalism and Social Democracy. Cambridge: Cambridge University Press

Radcliffe-Brown, Alfred. 1963. Preface. In African Political Systems, ed. Fortes Meyer and Edward Evan-Pritchard, xi-xxiii. London: International Institute of African Languages and Cultures and Oxford University Press

Risen, James and Laura Poitras. 2013a. NSA Gathers Data on Social Connections of US Citizens, The New York Times, September 28.

Risen, James and Laura Poitras. 2013b. NSA Report Outlined Goals for More Power, New York Times, November 22.

Robinson, Linda. 2012. The Future of Special Operations. Foreign Affairs 91 (6): 110-122.

Rogowski, Ronald and Duncan MacRae. 2008. Inequality and Institutions: What Theory, History, and (some) Data Tell us. In Democracy, Inequality and Representation: A Comparative Perspective, ed. Pabl Beramendi and Christopher Anderson, 354-386. New York: Russell Sage Foundation

Scahill, Jeremy. 2010. Obama's Expanding Covert War, The Nation, June 4 
Schmitt, Eric and Thom Shanker. 2013. A Commander Seeks to Chart a New Path for Special Operations. The New York Times, 1 May 1

Schmitt, Eric, Mark Mazzetti and Thom Shanker. 2012. Admiral Seeks Freer Hand in Deployment of Elite Forces. The New York Times, February 12

Shank, Michael and Elizabeth Beavers. 2013. America's Police are Looking more and more like the Military, The Guardian, October 7

Shanker, Thom. 2012. Floating Base Gives U.S. New Footing in the Persian Gulf. The New York Times, July 11

Singh, Joseph. 2012. Betting Against a Drone Arms Race. Time, August 13, http://nation.time.com/2012/08/13/betting-against-a-drone-arms-race/\#ixzz2h54oZUZx

Skocpol, Theda. 1979. States and Social Revolutions: A Comparative Analysis of France, Russia, and China. Cambridge: Cambridge University Press.

Skocpol, Theda. 1985. Bringing the State Back. In Strategies of Analysis in Current Research. In Bringing the State Back, ed. Peter Evens, Dietrich Rueschemeyer and Theda Skocpol, 3-43. Cambridge: Cambridge University Press.

Sokol, Ronald. 2010. Can the US Assassinate an American Citizen Living in Yemen? The Christian Science Monitor, September 29

Spiegel Staff. 2013. How the NSA and GCHQ Spied on OPEC. Spiegel Online, November 11, www.spiegel.de/international/world/how-the-nsa-and-gchq-spied-on-opec-a-932777.html

Stepak, Amir and Rachel Whitlack. 2012. The Battle over America's Foreign Policy Doctrine, Survival: Global Politics and Strategy 54 (5): 45-66.

Strawer, Bradley. 2012. The morality of drone warfare revisited. The Guardian, August 6 http://www.theguardian.com/commentisfree/2012/aug/06/morality-drone-warfare-revisited

Terdiman, Daniel. 2013. America's first next-gen aircraft carrier takes high tech to sea, CNET News, November 10, http://news.cnet.com/8301-11386_3-57611603-76/americas-first-next-gen-aircraftcarrier-takes-high-tech-to-seal

Tilly, Charles. 1975. The Formation of National States in Western Europe. Princeton, NJ: Princeton University Press.

Tilly, Charles. 1990. Coercion, Capital and European States, AD 990-1990. Oxford: Basil Blackwell

Tilly, Charles. 2009. Grudging Consent, Social Science Research Council, 27 May 2009

Turse, Nick. 2011. America's Secret Empire of Drone Bases, TomDispatch, October 16, http://www.tomdispatch.com/archive/175454/nick_turse_america\%27s_secret_empire_of_drone_b ases

Turse, Nick. 2012. The New Obama Doctrine, Tom Dispatch, June 18, http://www.tomdispatch.com/blog/175557

Van Creveld, Martin. 1999. The Rise and Decline of the State. Cambridge: Cambridge University Press.

Weigley, Russell. 1960. The American Way or War: A History of Untied States Military Strategy and Policy. Bloomington, IN: Indiana University Press.

Whitlock, Craig and Greg Miller. 2011. U.S. assembling secret drone bases in Africa, Arabian Peninsula, officials say. Washington Post, September 20

Widner, Jennifer. 1995. States and Statelessness in Late-Twentieth-Century Africa, Daedalus 124 (3): 129-153.

\section{About the Author}

Scott Timcke

Scott Timcke is a PhD candidate at the School of Communication, Simon Fraser University. His thesis, Luck and Liberty: The Political Economy of Life Chances addresses the egalitarian turn in liberal philosophy in light of implications of radical contingency. Other research interests include social inequality, class stratification, and strategic-military communication. 